\title{
Covid-19 Sürecinde Örgütsel Bağlılık: Öğretmenler Üzerine illişkisel Bir Analiz
}

\section{Organizational Commitment During The Covid-19 Period: A Relational Analysis on Teachers}

\author{
Mustafa ÖZGENEL ID , Doç. Dr., İstanbul Sabahattin Zaim Üniversitesi, mustafa.ozgenel@izu.edu.tr \\ Hanifi PARLAR D , Doç. Dr., İstanbul Ticaret Üniversitesi, hparlar@ticaret.edu.tr \\ Merve ATAÇ ${ }^{D}$, Öğr. Gör., Çanakkale Onsekiz Mart Üniversitesi, merveatac@comu.edu.tr \\ İsmail ATAÇ ${ }^{(D)}$,Erenköy Zihnipaşa Halk Eğitim Merkezi, atacismail10@gmail.com \\ Hilal Duygu ATAÇㄹ , Şehit Er Yıldıray Biroğlu illkokulu, hilalduygu@gmail.com
}

\begin{abstract}
Özgenel, M., Parlar, H., Ataç, M., Ataç, ì., ve Ataç, H. D. (2021). Covid-19 sürecinde örgütsel bağlılık: Öğretmenler üzerine ilişkisel bir analiz. Batı Anadolu Eğitim Bilimleri Dergisi, 12(2), 805-819.
\end{abstract}

Geliş tarihi: 03.02.2021

Kabul tarihi: 21.12 .2021

Yayımlanma tarihi: 28.12 .2021

\begin{abstract}
Öz. Okullar birer eğitim merkezidir ve en önemli amacı toplumda bulunan bireyleri yetiştirmektir. Nitelikli topluma sahip olmanın tek yolu, onları nitelikli eğitimden geçirmektir. Bu nedenle öğretmenlerin sahip olduğu örgütsel bağlıık, toplumun gelişimi için önemlidir. Pandemi dönemi, öğretmenlerin eğitim misyonlarını okuldan uzakta çevrimiçi olarak gerçekleştirmelerini sağlamıştır. Bu dönemde öğretmenlerin örgütsel bağ|ııılarını etkilemiş olabileceği öngörülmektedir. Bu çalışmada Koronavirüs'ün öğretmenler üzerinde oluşturduğu korku ve bu korkunun örgütsel bağlılık ile arasındaki ilişkinin incelenmesi amaçlanmıştır. Bu amaçla isstanbul ili içerisinde devlet okullarının farklı kademelerinde görev yapmakta olan 403 öğretmenden online anket yoluyla veriler toplanmıştır. Çalışmada veri toplama aracı olarak Örgütsel Bağlılık Ölçeği ve Koronavirüs Korkusu Ölçeği kullanılmıştır. Çalışmada öğretmenlerin COVID-19 korkuları cinsiyetlerine göre anlamlı farklıık göstermediği belirlenmiştir. Öğretmenlerin örgütsel bağlılıkları ile uyum ve özdeşleşme düzeylerine bakıldığında eğitim durumlarına göre anlamlı farklılık göstermezken; lisans mezunu olan öğretmenlerin örgütsel bağlılık içselleştirme düzeyleri, lisansüstü mezun olan öğretmenlere göre daha yüksek olduğu görülmüştür. Aynı şekilde lisans mezunu olan öğretmenlerin, lisansüstü mezunu öğretmenlere göre COVID-19'dan daha fazla korku duyduğu, öğretmenlerin kıdem yılı arttıkça da COVID-19 korkusunun arttığı tespit edilmiştir. Öğretmenlerin COVID-19 korkuları arttıkça, örgütsel/okula bağılık düzeyleri azalmakta olduğu görülmüştür. Sonuç olarak Covid-19 korkusu öğretmenlerin örgütsel bağlılığını olumsuz etkilediği belirlenmiştir.
\end{abstract}

\section{Anahtar Kelimeler: Covid-19, Covid-19 Korkusu, Örgütsel Bağlılık, Öğretmen.}

\begin{abstract}
Schools are educational centers and their the most important aim is to train personel in society. The only way to have qualified society is possiable to grow them by qualified training. Fort his reason the organisational commitment that the teachers have is importand for imroving the society. Pandemic period has made the teachers have their educational mission online away from the school. This period may have changes on teachers commitmnets. In this study, it is aimed to examine the fear caused by the Coronavirus on teachers and the relationship between this fear and organizational commitment. For this purpose, data were collected from 403 teachers working at different levels of public schools in Istanbul through an online survey. Organizational Commitment Scale and Coronavirus Fear Scale were used as data collection tools in the study. In the study, it was determined that teachers' fears of COVID-19 did not differ significantly according to their gender. When the organizational commitment of teachers and their level of adaptation and identification are
\end{abstract}


examined, there is no significant difference according to their educational status; It has been seen that the organizational commitment internalization levels of undergraduate teachers are higher than those of graduate teachers. Likewise, it has been determined that teachers with a bachelor's degree are more afraid of COVID-19 than teachers with a graduate degree, and the fear of COVID-19 increases as the seniority of the teachers increases. It has been observed that as teachers' fears of COVID-19 increase, their organizational/school commitment levels decrease. As a result, it has been determined that the fear of Covid-19 negatively affects teachers' organizational commitment.

Keywords: Covid-19, Fear of Covid-19, Organizational Commitment, Teacher. 


\section{Extended Abstract}

Introduction. Schools are educational centers and their the most important aim is to train personel in society. The only way to have qualified society is possiable to grow them by qualified training (Erdoğan, 2012). Fort his reason the organisational commitment that the teachers have is importand for imroving the society. Pandemic period has made the teachers have their educational mission online away from the school. This period may have changes on teachers commitmnets. Fort his reason the evaliation of the teachers organisational commitmnet is importand for definition of Covid19 pandemic that is effective on their commitment to their organisation. The purpose of this study to search the relation between the organisational commitment and the fear which is on teachers.

Method. In this study the fear which was caused by coronavirüs on the teachers and search fort he relation between the organisational commitment and this fear is purposed so it was done by relational scanning modal. The study group is consist of from the teachers who are teaching at the NAtional Education Minister's schools in the city of istanbul in year 2020-2021. In this study easy reaching sampling method is used. Fort he study 403 teachers were reached. To collect the data, the participants definer questions (age, sexulity, education, his/her degree, total working year, the type of school where she/he worked) the scale of his/her organisational comitment (BFKÖ) and the scale of coronavirüs fear were used. During the evaluation of the collected data from the scales, for statistical analysis IBM SPSS statistic program was used. The collected data's dominance and deformity scores were seen between -1 and +1 , parametic tests were done and it was decided that the collected data had shown normal distirubition. While having a independent group test to define if there is a meaningful diffrence between two groups, one way varyans analysis (ANOVA) test was done between more than two groups. For the purpose of definition the relation between changeables korolasyon analysis, for indepent changeables (Covid-19) for dependent changeables (organisational commitment) to see predict or not regrasyon analysis were done.

Results. According to the result of the study the teacher's fear from the covid-19 shows meaningful difference. Also the teacher's identificational organisationallevel shows meaningfull difference depending on their sexuality. In this study it was reported that the amount of covid-19 fear about the two year degree graduated teachers is more than the postgraduated teachers. The fear level of the teachers who have 21 year seniority and more have high more fear level than the teachers who has 10 year seniority less and the teachers who have seniority between 11 to 20 year. Also the teachers who are 51 years old have more fear than other aged teachers data was found. In other way of saying the covid-19 fear level of teachers who are 51 and over aged have more fear than 30 years old and less, 31 to 40 and 41 to 50 was drawed the attention. In another word, the teachers covid-19 fear has negative effect on their organisational/school commitmnet and adaptation level of their organisational commitmnet. It was determined that when the covid-19 fear of teachers increase their organisational/school commitment and organisational commitment decrease.

Discussion and Conclusion. Covid-19 fear level which the participant teachers have shows meaningfull difference dependince their sexulaty. Acording to Duman's study (2020) which was about the covid-19 fear and impationce for uncertainly on University student's indicate that there is no meaningfull difference on their scores depending on their different sexuality. Cao and friends (2020) reported on their study that was made with university students as a result of pandemic the stres on negative and emotion that students have don't show meaningfull difference. But Bakioğlu and friends (2020) found on their study that was on adult indivuals covid-19 fear has meaningfull high level on women. At this point lack of men participants was considered may effect the results. In our stdy the covid-19 fear of the students shows meaningfull difference according to their age. It was found that the covid-19 fear of the teachers are 51 and over aged have more fear level than other age group. On Bakioğlu and friend (2020) study which was on adult was seen that there is no meaningfull relation between the age of participants and covid-19 fear level, the individuale aged 
between 17 and 76 have equal covid-19 fear level. It is concidered that this was based on the teachers face to face work in the crowded atmosfere in literature. The covid-19 infection and mortality mat cause individuals psychological unwell and have fear. The fear which was caused by covid-19 may cause to have discrimination and increase the effects of disease in society (Ahursu and others, 2020). The schools which have face to face interference so they may have high infection too. The speed of the virus infection, catching disease and mortality may cause the covid-19 fear on teachers. When we check our study's result the teachers covid-19 fear is high and this fear effects their organisational commitment. It was noticed that when the teachers covid-19 fear increase their organisational commitment adaptation level decreases. In this period because of lack of organisational commitment, the safety if work place can not be seen. At the same time being away from school could cause alienation. The train may be given about virus contect, infection and the cause of disease to the teachers to reduce their covid-19 fear and to increase their organisational commitment. Also the vacination program which will be applied to teachers can cause to reduce the fear and help to continue face to face education. 


\section{Giriş}

Bir toplumun geliş̧mesi için toplumdaki kişilerin nitelikli olarak yetiştirilmesi ile mümkündür (Erdoğan, 2012). Okullar ise toplumun nitelikli insan yetiştirme ihtiyacını karşılayan örgütlerdir. Okullarda sunulan eğitim hizmetinin niteliğini belirleyen en önemli faktörlerin başında öğretmenler gelmektedir. Başka bir ifadeyle eğitim konusunda var olan amaçların gerçekleşmesi ve desteklenmesi için bu amaca istekli ve mesleki olarak yeterlilik algısı yüksek öğretmenlerin varlığına ihtiyaç duyulmaktadır (Eminoğlu Küçüktepe ve Erden, 2017). Bu açıdan öğretmenlerin örgütsel bağlılıkları okulların gelişimi ve başarısı açısından önemlidir. Çünkü öğretmenlerin düşük örgütsel bağlılıkları, eş zamanlı olarak öğrenci başarısını yakından etkilemekte olup, öğrenci başarısını da düşürmektedir (Firestone ve Pennel, 1993'ten akt. Balay, 2000).

Örgütsel bağılıık kavramı ilk olarak Whyte tarafından 1956 yılında ele alınmıştır. Bu kavram pek çok araştırmacı tarafından ele alınsa da örgütsel bağlııı kavramının ortak bir tanımı yapılamamıştır. Her araştırmacı kendi çalışma alanına göre örgütsel bağlılık kavramını tanımladığından dolayı bu kavram ile ilgili pek çok tanımlamaya rastlanmaktadır (Kaya, Küçük, Arslan, 2017). Meyer ve Allen (1991) örgütsel bağlılık kavramının pek çok tanımının yapılmasını bağıılığın çok boyutlu olmasına bağlamışlardır. Yapılan tanımlardan her biri örgütsel bağlılık kavramının farklı boyutlarını ele aldığından dolayı hiçbir tanıma doğru veya yanlış diyemeyiz. Örgütsel bağlılı̆ın tanımı ile ilgili tek bir görüşte birleşilmemiş olsa da çok boyutlu bir yapısı olduğu büyük ölçüde kabul görmüştür (Avcı ve Küçükusta, 2009). Örgütsel bağlılık; bireyin kişisel amaç, istek ve değerlerine etkisi olan, bunların oluşmasına ve gerçekleşmesine katkıda bulunan, içerisinde olduğu örgütün amaçlarına karşı bağlılıkla hizmet etme, örgüt için özverili davranma, kişinin kendisini örgüte adaması ve tutumları olarak tanımlanmaktadır (Eren, 2015). Bireylerin örgüte olan bağlılıkları iş ile ilgili davranışlarında kritik bir öneme sahiptir. Kendilerini örgüte ait hissetmeyen, örgütün üyesi olarak görmeyen bireylerin işe geç kalma, devamsızlık yapma, performans düşüklüğü ve işten ayrılma gibi davranışları göstermeleri kaçınılmazdır. Buna karşın örgütsel bağııığı artan bireylerin bu davranışları göstermeyeceği ve iş performansının artacağı göz ardı edilmemelidir (Gümüş ve Sezgin, 2012).

Örgütsel bağlılık ile ilgili literatür incelendiğinde üzerinde en fazla durulan sınıflandırma Allen ve Meyer (1990) tarafından yapılan sınıflandırma olduğu görülmektedir. Allen ve Meyer örgütsel bağ|ılığı üç boyutta incelemişlerdir. Duygusal Bağlıık: Duygusal bağılık boyutunda gönüllülük önemlidir ve işgörenler örgüt ile duygusal yakınlık kurmaktadırlar. Bu bağlılık boyutunda örgütte kalma nedeni olarak işgörenin örgüt ile bütünleşmesi ve özdeşleşmesi görülmektedir (Balay, 2000). Duygusal bağ|ılık diğer bağ|ılık çeşitleri arasında en güçlü ve en çok istenen bağ|ılık türüdür. Bu bağlılık türünde çalışan gerekli durumlarda kendi çıkarlarından vazgeçerek örgüte ve örgüt çıkarları doğrultusunda hareket etmekten gurur duyabilmektedir (Eren, 2015). Devam Bağlıığı: Bu bağlılık türü çalışanın örgüt için yaptığı yatırımlar sonucunda örgüte karşı oluşan bağlılık olarak ele alınmakta ve çalışanın örgütten ayrılması durumunda karşı karşıya kalacağı olumsuzlukları ve maddi kayıpları göze alarak zorunlu bir şekilde örgütte kalmaya devam etmesi olarak tanımlanabilir. Devam bağlılı̆ı çalışılan süre, harcanan emek, elde edilen statü ve para gibi kazanımların örgütten ayrılma durumunda kaybedileceği düşünülerek, örgütte kalmaya devam etme gereksinimidir (Güllüoğlu, 2011). Normatif bağlıık: Normatif bağlıık, çalışanın örgüte karşı geliştirmiş olduğu bağlıığı bir vazife olarak benimsemesi ve bu bağııı̆̆ın doğru olduğunu düşünmesinden kaynaklanır. Bu bağlılık çalışanın örgüte karşı taşımış olduğu yükümlülük ve zorunluk nedeniyle kendisini örgütte kalmaya devam etme zorunluluğunda hissetmesine dayanmaktadır. Ancak bu bağlııı devam bağııı̆̆ gibi bir çıkar ile ilgili değil ahlaki duygularla ilgilidir (Gül, 2002). Örgütsel bağlılığın bu üç boyutunda meydana gelen artı̧̧ işgörenlerin örgütte kalma davranışını devam ettirdiklerini göstermektedir. Duygusal bağılıkta örgütte kalma davranışı isteğe, devam bağlılı̆̆ında örgütte kalma davranışı gereksinime, normatif bağlılıkta ise zorunluluğa dayanmaktadır (Balay, 2004). 
Örgütsel bağlılığa etki eden birçok faktör vardır. Bunların başında örgütün özellikleri olan; örgütsel destek, ücret, rol stresi ve liderlik özellikleri yer almaktadır. Bu faktörler arasında yer alan rol stresi pandemi sürecinde öğretmenleri yakından etkilemektedir. Bu durum öğretmenlerde, süreç içerisindeki iş tanımlarının yetersizliği nedeniyle rol belirsizliğine (role ambuguity); beklentiler arasındaki uyumsuzluk sebebiyle rol çelişkisine (role conflict) ve uygun olmayan zaman ve enerji beklentisi gibi fazla iş yükü (role overload) nedeniyle rol stresi oluşturabilmektedir (Starnes ve Truhon, 2006). Bu süreçte yapılacak olan iş tanımın belirsizliği öğretmenlerde var olan örgütsel bağ|ılı̆ı da etkilemiş olabileceği düşünülmektedir. Örgütsel bağlılığı etkileyen bir diğer etmen ise öğretmenlerin beklentilerdir. Beklentilerin karşılanması ile öğretmenlerin örgüte bağlılı̆̆ının da artacağı öngörülmektedir. Bir öğretmenin örgütsel bağlılı̆ı ne kadar güçlü ise kendisine düşen görevleri yerine getirecek, böylece de öğrenci başarısı ve okul etkililiği de olumlu yönde artmış olacaktır (Dumay ve Galand, 2012; Lai, Luen, Chai ve Ling, 2014).

Pandemi süreci devam etmekte olup, uzun süreli sosyal izolasyonun olumsuz etkileri ekonomik, toplumsal ve kültürel olarak devam etmektedir. Genel nüfus üzerinde COVID-19'un ruhsal sağı̆̆ğı etkilediği de yapılan çalışmalar sonucunda belirlenmiştir (Ornell ve diğerleri, 2020). Wang ve ark. (2020) yapmış olduğu çalışmada, pandemi sürecinde bireylerde görülen ilk semptomların stres, anksiyete ve depresyon olduğu görülmüştür. Ahorsu ve ark. yapmış olduğu çalışmada da bireylerin COVID-19'a karşı büyük bir stres yaşadıklarını ve bu süreçte gerçeği düşünmede zorluk yaşadıklarını belirtmiştir (Ahorsu vd., 2020). Pandemi aynı zamanda eğitime ara verilmek zorunda bırakılan öğretmen ve öğrenciler üzerinde de uzun vadede olumsuz etkileri olacağı görülmektedir. Cao ve ark. (2020) bu yönde yapmış oldukları çalışmasında Çin'deki öğrenci nüfusunun \%21,3'ünün hafif kaygı yaşadığını, \%2,7'sinin orta derecede kaygı bildirdiğini ve \%0,9'unun ciddi endişe yaşadığı görülmüştür. Duman'ın (2020) öğrenciler üzerinde yapmış olduğu çalışmada da öğrencilerin COVID-19 korkusu orta düzeyde bulunmuştur. Pandemi sırasında öğretmen ve öğrencilerin yaşadığı bu stres ve kaygı, COVID19 korkusudur. Bu korku özellikle enfekte olma ya da sevdiklerine bulaştırmadır. Colizzi ve ark. (2020) yapmış olduğu çalışmada bireylerde yakın zamanda enfeksiyon korkusunun oluşabileceğine dikkat çekmektedir.

Türkiye'de resmi olarak bildirilen ilk COVID-19 vakası 10 Mart 2020 tarihidir. O tarihten sonra vaka sayıları hızla yükselmeye başlamıştır. Türkiye Cumhuriyeti hükümeti vatandaşlarını evde kalmaya çağırdı ve 18 Nisan itibariyle 30 ile seyahat kısıtlaması getirildi (iç̧ Işleri Bakanlığı, 2020). Pandeminin ne kadar süreceğine dair herhangi bir tahmin de bulunmak güçtür. Bu belirsizlik, virüsün oldukça bulaştırıcı olması ve tedavisindeki bilinmezliktir. Ayrıca pandemi süreci bireysel, örgütsel ve toplumsal olarak etkisi uzun sürebilecek belirsizlikler getirmiştir. Bu süreçte öğretmenler okul dışında online olarak görevlerini sürdürmek zorunda kalmışlardır. Covid-19 sürecinde yaşanan belirsizlikler ve Covid-19 korkusu öğretmenlerin örgütsel bağlılıklarında değişime neden olabilir. Bu çalışmada Koronavirüs'ün öğretmenler üzerinde oluşturduğu korku ve bu korkunun örgütsel bağlılık ile arasındaki ilişkinin incelenmesi amaçlanmıştır.

\section{Yöntem}

\section{Model}

Bu araştırmada, Koronavirüs'ün öğretmenler üzerinde oluşturduğu korku ve bu korkunun örgütsel bağııık ile arasındaki ilişkinin incelenmesi amaçlandığından, araştırma ilişkisel tarama modeline göre gerçekleştirilmiştir. İlişkisel modelde amaç değişkenler arasındaki ilişkiyi tanımlamak ve açıklamaktır (Brink ve Wood, 1998). 


\section{Çalışma gurubu}

Öğretmenlerin örgütsel bağlılık ile koronavirüs korkusu arasındaki ilişkiyi ölçmeyi amaçlayan araştırmanın çalışma grubunu, 2020-2021 Eğitim Öğretim yılı içerisinde İstanbul ilinde, Milli Eğitim Bakanlığına bağlı resmi devlet okullarında görev yapmakta olan öğretmenler oluşturmaktadır. Araştırmada kolay ulaşılır örnekleme yöntemi uygulanmıştır. Araştırma için 403 öğretmene ulaşıımıştır. Öğretmenlerin \%63.3'ü (252) kadın, \%36.7'si (146) erkektir. Öğretmenlerin \%77.6'sı (309) lisans mezunu, \%22.4'ü (89) lisansüstü eğitim mezunudur. Öğretmelerin \%17.1'i (68) 30 yaşın ve altında olup, \%44.2'si (176) 11-20 yıl arası kıdeme sahip ve \%38.7'si (154) ortaokul kademesinde görev yapmaktadır. Uygulanan ölçeklerde eksik ve boş olan ölçekler değerlendirmeye alınmamıştır.

\section{Veri toplama araçları}

Verilerin toplanmasında katılımcıların tanımlayıcı özelliklerini içeren sorular (yaş, cinsiyet, mezuniyet durumu, kıdem yılı, görev aldığı okul türü vb.), Örgütsel Bağılık Ölçeği (BFKÖ) ve Koronavirüs Korkusu Ölçeği kullanılmıştır.

Örgütsel Bağlıık Ölçeği: Örgütsel Bağlılık Ölçeği Balay (2000) tarafından geliştirilmiştir. Ölçeğin üç boyutu bulunmaktadır. "Uyum" boyutunda 8 madde, "Özdeşleşme" boyutunda 8 madde ve "içselleştirme" boyutunda 11 madde olmak üzere ölçekte toplam 27 madde yer almaktadır. Ölçek beşli likert tipinde hazırlanmıştır. Katılımcıların ölçekteki ifadelere ne düzeyde katıldıkları istenmektedir. Ölçekteki en düşük puan 1 , en yüksek puan $5^{\prime}$ tir. Balay $(2000)$ tarafından yapılan Cronbach's Alpha analiz sonucunda, ölçek geneli .82, uyum boyutunda .87 , özdeşleşme boyutunda .87 ve içselleştirme boyutunda ise, .92 değerlerini bulunmuştur. Bu araştırmada ölçeğin güvenirlik katsayısı 0.900 olarak hesaplanmıştır.

Koronavirüs (COVID-19) Korkusu Ölçeği (BAÖ): Ölçek, Ahorsu ve arkadaşları (2020) tarafından geliştirilmiş ve Bakioğlu ve ark. (2020) tarafından Türkiye koşullarına uyarlanmıştır. Yedi maddelik tek boyutlu bir ölçektir. 5 puanlık Likert tipi bir derecelendirme sistemine sahiptir. Ölçeğin maddelerinden alınan toplam puan bireyin yaşadığı Koronavirüs (Covid-19) korkusu düzeyini göstermektedir. Ölçekten alınabilecek puanlar 7 ile 35 arasında değişmektedir. Ölçekten alınan yüksek puan yüksek düzeyde Koronavirüs korkusu yaşamak anlamına gelmektedir. Ölçeğin Cronbach alfa iç tutarlılık katsayısı 0.82 'dir. Bu araştırmada ölçeğin güvenirlik katsayısı 0.930 olarak hesaplanmıştır.

\section{Verilerin analizi}

Çalışmadan elde edilen bulgular değerlendirilirken, istatiksel analizler için IBM SPSS Statisic programı kullanılmıştır. Çalışma verileri değerlendirilirken verilerin normal dağılım gösterip göstermediğine karar vermek için basıklık ve çarpıklık değerleri incelenerek değerlendirilmiştir.

Tablo 1. COViD-19 Korkusu ve Örgütsel Bağlılık Ölçeklerine Ait Basıklık ve Çarpıklık Değerleri

\begin{tabular}{lccccc}
\hline Değişkenler & $\mathbf{N}$ & $\mathbf{M}$ & sd & Çarpıklık & Basıklık \\
\hline COVID Korkusu & 398 & 3.257 & 1.023 & -.307 & -.663 \\
\hline Bağlılık Uyum & 398 & 2.458 & 1.025 & .664 & -.355 \\
\hline Bağlılık Özdeşleşme & 398 & 3.453 & .825 & -.099 & -.754 \\
\hline Bağlılık İçselleştirme & 398 & 3.644 & .756 & -.446 & -.183 \\
\hline Örgütsel Bağlılık Toplam & 398 & 3.236 & .570 & .804 & .531 \\
\hline
\end{tabular}

Tablo 1 incelendiğinde ölçeklerden toplanan verilerin basıklık ve çarpıklık değerlerinin -1 ile +1 arasında olduğu görülmüş ve verilerin normal dağılım gösterdiğine karar verilmiş ve parametrik testler yapılmıştır. İi grup arasında anlamlı farklıık olup olmadığını belirlemek için bağımsız grup t 
testi yapılırken, ikiden fazla grup arası karşılaştırılmasında tek yönlü varyans analizi (ANOVA) testi yapılmıştır. Değişkenler arasındaki ilişkiyi belirlemek amacıyla korelasyon analizi, bağımsız değişkenin (COVID-19), bağımlı değişkeni (örgütsel bağııık) yordayıp yordamadığını belirlemek için regresyon analizi yapılmıştır.

\section{Bulgular}

Öğretmenlerin COVID-19 korkusu ve örgütsel bağlılık düzeylerinin cinsiyetlerine göre anlamlı farklıık gösterip göstermediğinin tespit etmek amacıyla yapılan bağımsız grup t testi sonuçları Tablo 2'de sunulmuştur.

Tablo 2: Öğretmenlerin COVID-19 Korkusu ve Örgütsel Bağlılık Düzeylerinin Cinsiyetlerine Göre Karşılaştırılması

\begin{tabular}{|c|c|c|c|c|c|c|c|}
\hline Değişkenler & Gruplar & $\mathbf{N}$ & $M$ & SD & $\mathbf{t}$ & df & $\mathbf{p}$ \\
\hline \multirow{2}{*}{ COVID-19 korkusu } & Kadın & 252 & 3.28 & .972 & \multirow{2}{*}{.784} & \multirow{2}{*}{396} & \multirow{2}{*}{.450} \\
\hline & Erkek & 146 & 3.20 & 1.10 & & & \\
\hline \multirow{2}{*}{ Örgütsel Bağlılık Uyum } & Kadın & 252 & 2.33 & .950 & \multirow{2}{*}{-3.196} & \multirow{2}{*}{396} & \multirow{2}{*}{.002} \\
\hline & Erkek & 146 & 2.66 & 1.08 & & & \\
\hline \multirow{2}{*}{$\begin{array}{l}\text { Örgütsel Bağlılık } \\
\text { Özdeşleşme }\end{array}$} & Kadın & 252 & 3.45 & .840 & \multirow{2}{*}{.178} & \multirow{2}{*}{396} & \multirow{2}{*}{.859} \\
\hline & Erkek & 146 & 3.44 & .803 & & & \\
\hline \multirow{2}{*}{$\begin{array}{l}\text { Örgütsel Bağ|ılık } \\
\text { İçselleştirme }\end{array}$} & Kadın & 252 & 3.65 & .749 & \multirow{2}{*}{.369} & \multirow{2}{*}{396} & \multirow{2}{*}{.712} \\
\hline & Erkek & 146 & 3.62 & .768 & & & \\
\hline \multirow{2}{*}{$\begin{array}{l}\text { Örgütsel Bağlılık } \\
\text { Toplam }\end{array}$} & Kadın & 252 & 3.20 & .541 & \multirow{2}{*}{-1.388} & \multirow{2}{*}{396} & \multirow{2}{*}{.181} \\
\hline & Erkek & 146 & 3.28 & .614 & & & \\
\hline
\end{tabular}

Tablo 2'ye göre öğretmenlerin COVID-19 korkuları cinsiyetlerine göre anlamlı farklılık göstermemektedir ( $p>05)$. Yine öğretmenlerin örgütsel bağlılıkları ile örgütsel bağlılık özdeşleşme ve içselleştirme düzeyleri cinsiyetlerine göre anlamlı farklılık göstermemektedir ( $p>.05)$. Ancak öğretmenlerin örgütsel bağılık alt boyutu olan örgütsel bağlılık uyum düzeyleri cinsiyetlerine göre anlamlı farklııı göstermektedir $(p<.05)$. Erkek öğretmenlerin örgütsel bağlılık uyum düzeyleri $(M=2.669 ; S D=1.082)$, kadın öğretmenlerin uyum düzeylerinden $(M=2.336 ; S D=.950)$ daha yüksektir.

Öğretmenlerin COVID-19 korkusu ve örgütsel bağlılık düzeylerinin eğitim durumlarına göre anlamlı farklılık gösterip göstermediğinin tespit etmek amacıyla yapılan bağımsız grup $t$ testi sonuçları Tablo 3'te sunulmuştur.

Tablo 3: Öğretmenlerin COVID-19 Korkusu ve Örgütsel Bağlılık Düzeylerinin Eğitim Durumlarına Göre Karşılaştırılması

\begin{tabular}{|c|c|c|c|c|c|c|c|}
\hline Değişkenler & Gruplar & $\mathbf{N}$ & $M$ & SD & $t$ & df & $p$ \\
\hline \multirow{2}{*}{ COVID-19 korkusu } & Lisans & 309 & 3.32 & 1.03 & \multirow{2}{*}{2.438} & \multirow{2}{*}{396} & \multirow{2}{*}{.015} \\
\hline & Lisansüstü & 89 & 3.02 & .969 & & & \\
\hline \multirow{2}{*}{ Örgütsel Bağlılık Uyum } & Lisans & 309 & 2.44 & 1.01 & \multirow{2}{*}{-.568} & \multirow{2}{*}{396} & \multirow{2}{*}{.570} \\
\hline & Lisansüstü & 89 & 2.51 & .990 & & & \\
\hline \multirow{2}{*}{$\begin{array}{l}\text { Örgütsel Bağlılık } \\
\text { Özdeşleşme }\end{array}$} & Lisans & 309 & 3.46 & .811 & \multirow{2}{*}{.467} & \multirow{2}{*}{396} & \multirow{2}{*}{.641} \\
\hline & Lisansüstü & 89 & 3.41 & .879 & & & \\
\hline \multirow{2}{*}{$\begin{array}{l}\text { Örgütsel Bağlılık } \\
\text { İçselleştirme }\end{array}$} & Lisans & 309 & 3.68 & .745 & \multirow{2}{*}{2.008} & \multirow{2}{*}{396} & \multirow{2}{*}{.045} \\
\hline & Lisansüstü & 89 & 3.50 & .779 & & & \\
\hline \multirow{2}{*}{ Örgütsel Bağ|ılık Toplam } & Lisans & 309 & 3.25 & .580 & \multirow{2}{*}{.982} & \multirow{2}{*}{396} & \multirow{2}{*}{.327} \\
\hline & Lisansüstü & 89 & 3.18 & .533 & & & \\
\hline
\end{tabular}

Tablo 3'e göre öğretmenlerin COVID-19 korkuları eğitim durumlarına göre anlamlı farklııı göstermektedir ( $p .<5)$. Lisans mezunu olan öğretmenlerin Covid-19 korkuları, lisansüstü mezun olan 
öğretmenlere göre daha yüksektir. Başka bir ifadeyle lisans mezunu olan öğretmenler ( $M=3.324$; $S D=1.030)$, lisansüstü öğretmenlere ( $M=3.025 ; S D=.969)$ göre COVID-19'dan daha fazla korku duymaktadır. Öğretmenlerin örgütsel bağlııkları ile uyum ve özdeşleşme düzeyleri eğitim durumlarına göre anlamlı farklılık göstermezken ( $p>.05)$; örgütsel bağlılık içselleştirme düzeyleri anlamlı farklılık göstermektedir $(p<.05)$. Lisans mezunu olan öğretmenlerin örgütsel bağılık içselleştirme düzeyleri ( $M=3.685 ; S D=.745)$, lisansüstü mezun olan öğretmenlere $(M=3.503 ; S D=.779)$ göre daha yüksektir.

Öğretmenlerin COVID-19 korkusu ve örgütsel bağlılık düzeylerinin mesleki kıdemlerine göre anlamlı farklılık gösterip göstermediğinin tespit etmek amacıyla yapılan tek yönlü varyans analizi (ANOVA) testi sonuçları Tablo 4'te sunulmuştur.

Tablo 4: Öğretmenlerin COVID-19 Korkusu ve Örgütsel Bağlılık Düzeylerinin Mesleki Kıdemlerine Göre Karşılaştırılması

\begin{tabular}{|c|c|c|c|c|c|c|c|c|c|c|c|}
\hline & Kıdem & $\mathbf{N}$ & M & SD & $\begin{array}{l}\text { Varyansın } \\
\text { Kaynağı }\end{array}$ & KT & df & KO & $\mathbf{F}$ & $\mathbf{p}$ & Fark \\
\hline \multirow{4}{*}{ ○ी } & A-10 yıl ve altı & 117 & 3.16 & .96 & G. Arası & 7.27 & 2 & 2.52 & \multirow{4}{*}{3.512} & \multirow{4}{*}{.031} & \multirow{4}{*}{$\begin{array}{l}C>A \\
C>B\end{array}$} \\
\hline & B-11-20yıl arası & 176 & 3.18 & 1.03 & G. İçi & 408.8 & 395 & .22 & & & \\
\hline & $\mathrm{C}-21 \mathrm{yll}+$ & 105 & 3.48 & 1.05 & Toplam & 416.1 & 397 & & & & \\
\hline & Toplam & 398 & 3.25 & 1.02 & & & & & & & \\
\hline \multirow{4}{*}{ 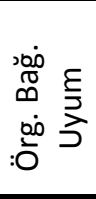 } & A-10 yıl ve altı & 117 & 2.47 & 1.05 & G. Arası & .276 & 2 & 2.52 & \multirow{4}{*}{.134} & \multirow{4}{*}{.874} & \multirow{4}{*}{---} \\
\hline & B-11-20yıl arası & 176 & 2.43 & .99 & G. İçi & 406.7 & 395 & .22 & & & \\
\hline & $\mathrm{C}-21 \mathrm{yıl}+$ & 105 & 2.49 & .99 & Toplam & 406.9 & 397 & & & & \\
\hline & Toplam & 398 & 2.45 & 1.01 & & & & & & & \\
\hline \multirow{4}{*}{ 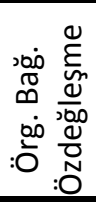 } & A-10 yıl ve altı & 117 & 3.37 & .84 & G. Arası & 3.70 & 2 & 2.52 & \multirow{4}{*}{2.737} & \multirow{4}{*}{.066} & \multirow{4}{*}{---} \\
\hline & B-11-20yıl arası & 176 & 3.40 & .82 & G. İçi & 267.0 & 395 & .22 & & & \\
\hline & C-21 yıl + & 105 & 3.61 & .78 & Toplam & 270.7 & 397 & & & & \\
\hline & Toplam & 398 & 3.45 & .82 & & & & & & & \\
\hline \multirow{4}{*}{ 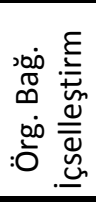 } & A-10 yıl ve altı & 117 & 3.59 & .75 & G. Arası & 3.55 & 2 & 2.52 & \multirow{4}{*}{3.141} & \multirow{4}{*}{.044} & \multirow{4}{*}{$\begin{array}{l}C>A \\
C>B\end{array}$} \\
\hline & B-11-20yıl arası & 176 & 3.58 & .77 & G. İçi & 223.3 & 395 & .22 & & & \\
\hline & C-21 yıl + & 105 & 3.80 & .71 & Toplam & 226.9 & 397 & & & & \\
\hline & Toplam & 398 & 3.64 & .75 & & & & & & & \\
\hline \multirow{4}{*}{ 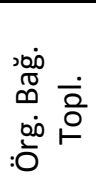 } & A-10 yıl ve altı & 117 & 3.19 & .58 & G. Arası & 2.10 & 2 & 2.52 & \multirow{4}{*}{3.275} & \multirow{4}{*}{.039} & \multirow{4}{*}{$\begin{array}{l}C>A \\
C>B\end{array}$} \\
\hline & B-11-20yıl arası & 176 & 3.19 & .54 & G. İçi & 126.8 & 395 & .22 & & & \\
\hline & $\mathrm{C}-21 \mathrm{yıl}+$ & 105 & 3.35 & .57 & Toplam & 128.9 & 397 & & & & \\
\hline & Toplam & 398 & 3.23 & .57 & & & & & & & \\
\hline
\end{tabular}

Tablo 4'e göre öğretmenlerin COVID-19 korkuları kıdemlerine göre anlamlı farklılık göstermektedir (p.<5). 21 yıl ve üzeri kıdeme sahip olan öğretmenlerin COVID-19 korku düzeyleri $(M=3.48 ; S D=1.02), 10$ yıl ve altı $(M=3.16 ; S D=.96)$ ve $11-20$ yıl arası $(M=3.18 ; S D=1.03)$ kıdeme sahip olan öğretmenlerin korku düzeylerinden daha yüksektir. Öğretmenlerin örgütsel bağlılık uyum ve özdeşleşme düzeyleri öğretmelerin kıdemlerine göre anlamlı farklılık göstermezken ( $p>05)$; öğretmenlerin örgütsel bağlııkları ile örgütsel bağlılık içselleştirme düzeyleri öğretmenlerin kıdemlerine göre anlamlı farklılık göstermektedir $(p<.05)$. 21 yıl ve üzeri kıdeme sahip olan öğretmenlerin örgütsel bağlılıkları $(M=3.35 ; S D=.57)$ ile içselleştirme düzeyleri $(M=3.80 ; S D=.71), 10$ yıl ve altı kıdeme sahip olan öğretmenlerin örgütsel bağlılıkları $(M=3.19 ; S D=.58)$ ile içselleştirme düzeylerinden ( $M=3.59 ; S D=.75)$ daha yüksektir. Yine 21 yıl ve üzeri kıdeme sahip olan öğretmenlerin örgütsel bağlılıkları ( $M=3.35 ; S D=.57)$ ile içselleştirme düzeyleri $(M=3.80 ; S D=.71), 11-20$ yıl arası kıdeme sahip olan öğretmenlerin örgütsel bağlılıkları (M=3.19; $S D=.54)$ ile içselleştirme düzeylerinden $(\mathrm{M}=3.58 ; \mathrm{SD}=.77)$ daha yüksektir. 
Öğretmenlerin COVID-19 korkusu ve örgütsel bağlılık düzeylerinin yaşlarına göre anlamlı farklılık gösterip göstermediğinin tespit etmek amacıyla yapılan tek yönlü varyans analizi (ANOVA) testi sonuçları Tablo 5'te sunulmuştur.

Tablo 5: Öğretmenlerin COVID-19 Korkusu ve Örgütsel Bağlılık Düzeylerinin Yaşlarına Göre Karşılaştırılması

\begin{tabular}{|c|c|c|c|c|c|c|c|c|c|c|c|}
\hline & Yaş & $\mathbf{N}$ & M & sd & $\begin{array}{l}\text { Varyansın } \\
\text { Kaynağı }\end{array}$ & KT & df & KO & $\mathbf{F}$ & $\mathbf{p}$ & Fark \\
\hline \multirow{5}{*}{ 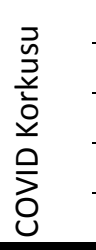 } & A-30 yaş ve altı & 68 & 3.17 & 1.01 & G. Arası & 33.15 & 3 & 11.05 & \multirow{5}{*}{11.370} & \multirow{5}{*}{.000} & \multirow{5}{*}{$\begin{array}{l}D>A \\
D>B \\
D>C\end{array}$} \\
\hline & B-31-40 yaş arası & 152 & 3.01 & .97 & G. İçi & 382.9 & 394 & .97 & & & \\
\hline & C-41-50 yaş arası & 125 & 3.30 & 1.00 & Toplam & 416.1 & 397 & & & & \\
\hline & D-51 yaş ve üzeri & 53 & 3.92 & .93 & & & & & & & \\
\hline & Toplam & 398 & 3.25 & 1.02 & & & & & & & \\
\hline \multirow{5}{*}{ 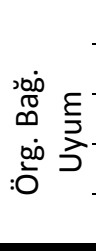 } & A-30 yaş ve altı & 68 & 2.59 & 1.08 & G. Arası & 9.13 & 3 & 3.04 & \multirow{5}{*}{3.014} & \multirow{5}{*}{.030} & \multirow{5}{*}{$\begin{array}{l}D>B \\
D>C\end{array}$} \\
\hline & B-31-40 yaş arası & 152 & 2.35 & .95 & G. İçi & 397.8 & 394 & 1.01 & & & \\
\hline & C-41-50 yaş arası & 125 & 2.37 & .96 & Toplam & 406.9 & 397 & & & & \\
\hline & D-51 yaş ve üzeri & 53 & 2.77 & 1.12 & & & & & & & \\
\hline & Toplam & 398 & 2.45 & 1.01 & & & & & & & \\
\hline \multirow{5}{*}{ 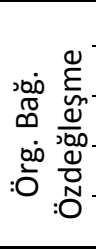 } & A-30 yaş ve altı & 68 & 3.41 & .85 & G. Arası & 5.84 & 3 & 1.94 & \multirow{5}{*}{2.895} & \multirow{5}{*}{.035} & \multirow{5}{*}{$D>B$} \\
\hline & B-31-40 yaş arası & 152 & 3.35 & .77 & G. İçi & 264.8 & 394 & .67 & & & \\
\hline & C-41-50 yaş arası & 125 & 3.47 & .85 & Toplam & 270.7 & 397 & & & & \\
\hline & D-51 yaş ve üzeri & 53 & 3.73 & .81 & & & & & & & \\
\hline & Toplam & 398 & 3.45 & .82 & & & & & & & \\
\hline \multirow{5}{*}{ 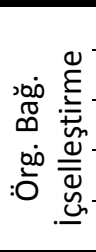 } & A-30 yaş ve altı & 68 & 3.67 & .72 & G. Arası & 3.49 & 3 & 1.16 & \multirow{5}{*}{2.053} & \multirow{5}{*}{.106} & \multirow{5}{*}{--- } \\
\hline & B-31-40 yaş arası & 152 & 3.54 & .69 & G. İçi & 223.4 & 394 & .56 & & & \\
\hline & C-41-50 yaş arası & 125 & 3.66 & .82 & Toplam & 226.9 & 397 & & & & \\
\hline & D-51 yaş ve üzeri & 53 & 3.83 & .76 & & & & & & & \\
\hline & Toplam & 398 & 3.64 & .75 & & & & & & & \\
\hline \multirow{5}{*}{ 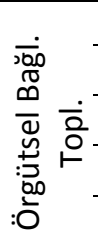 } & A-30 yaş ve altı & 68 & 3.27 & .66 & G. Arası & 5.13 & 3 & 1.71 & \multirow{5}{*}{5.447} & \multirow{5}{*}{.001} & \multirow{5}{*}{$\begin{array}{l}D>B \\
D>C\end{array}$} \\
\hline & B-31-40 yaş arası & 152 & 3.13 & .49 & G. İçi & 123.8 & 394 & .31 & & & \\
\hline & C-41-50 yaş arası & 125 & 3.22 & .52 & Toplam & 128.9 & 397 & & & & \\
\hline & D-51 yaş ve üzeri & 53 & 3.49 & .67 & & & & & & & \\
\hline & Toplam & 398 & 3.23 & .57 & & & & & & & \\
\hline
\end{tabular}

Tablo 5'e göre öğretmenlerin COVID-19 korkuları yaşlarına göre anlamlı farklılık göstermektedir ( $p .<5)$. 51 yaş ve üzerinde olan öğretmenlerin Covid-19 korku düzeyleri, diğer yaş gurubundaki öğretmenlerin korku düzeylerinden daha yüksektir. Başka bir ifadeyle, 51 yaş ve üzerinde olan öğretmenlerin Covid-19 korku düzeyleri ( $M=3.97$; $S D=.93), 30$ yaş ve altı $(M=3.17$; $S D=1.01), 31-40$ yaş $(M=3.01 ; S D=.97)$ ve $41-50$ yaş ( $M=3.30 ; S D=1.00)$ arası öğretmenlerin COVID-19 korku düzeylerinden daha fazladır. Öğretmenlerin örgütsel bağlılık içselleştirme düzeyleri yaşlarına göre anlamlı farklılık göstermezken $(p<.05)$; örgütsel bağlııkları ile uyum ve özdeşleşme düzeyleri yaşlarına göre anlamlı farklıık göstermektedir. 51 yaş ve üzerinde olan öğretmenlerin örgütsel bağlılık uyun düzeyleri ( $M=2.778 ; S D=1.123), 31-40$ yaş $(M=2.356 ; S D=.955)$ ve $41-50$ yaş ( $M=2.375 ; S D=.963$ ) arası öğretmenlerin uyum düzeylerinden daha yüksektir. 51 yaş ve üzerinde olan öğretmenlerin örgütsel bağlılık özdeşleşme düzeyleri ( $M=3.735 ; S D=.813), 31-40$ yaş $(M=3.354 ; S D=.777)$ arası öğretmenlerin özdeşleşme düzeylerinden daha yüksektir. Son olarak 51 yaş ve üzerinde olan öğretmenlerin örgütsel bağılıık düzeyleri ( $M=3.494 ; S D=.670)$, 31-40 yaş ( $M=3.137 ; S D=.491)$ ve 41-50 yaş ( $M=3.224 ; S D=.26)$ arası öğretmenlerin örgütsel bağlılık düzeylerinden daha yüksektir. 
Öğretmenlerin COVID-19 korkusu ve örgütsel bağlılık düzeylerinin görev yaptıkları okul kademelerine göre anlamlı farklılık gösterip göstermediğinin tespit etmek amacıyla yapılan tek yönlü varyans analizi (ANOVA) testi sonuçları Tablo 6'da sunulmuştur.

Tablo 6: Öğretmenlerin COVID-19 Korkusu ve Örgütsel Bağlılık Düzeylerinin Okul Türüne Göre Karşılaştırılması

\begin{tabular}{|c|c|c|c|c|c|c|c|c|c|c|c|}
\hline & Okul Kademesi & $\mathbf{N}$ & M & sd & $\begin{array}{l}\text { Varyansın } \\
\text { Kaynağı }\end{array}$ & KT & df & KO & $\mathbf{F}$ & $p$ & Fark \\
\hline \multirow{4}{*}{ 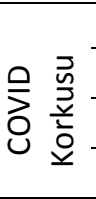 } & A-ilkokul & 135 & 3.29 & 1.14 & G. Arası & 2.30 & 2 & 2.52 & \multirow{4}{*}{1.100} & \multirow{4}{*}{.334} & \multirow{4}{*}{---} \\
\hline & B-Ortaokul & 154 & 3.16 & .94 & G. İçi & 413.8 & 395 & .22 & & & \\
\hline & C-Lise & 109 & 3.34 & .97 & Toplam & 416.1 & 397 & & & & \\
\hline & Toplam & 398 & 3.25 & 1.02 & & & & & & & \\
\hline \multirow{4}{*}{ 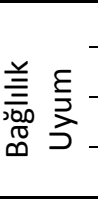 } & A-ilkokul & 135 & 2.56 & 1.02 & G. Arası & 4.63 & 2 & 2.52 & \multirow{4}{*}{2.276} & \multirow{4}{*}{.104} & \multirow{4}{*}{---} \\
\hline & B-Ortaokul & 154 & 2.32 & .93 & G. İçi & 402.3 & 395 & .22 & & & \\
\hline & C-Lise & 109 & 2.51 & 1.08 & Toplam & 406.9 & 397 & & & & \\
\hline & Toplam & 398 & 2.45 & 1.01 & & & & & & & \\
\hline \multirow{4}{*}{ 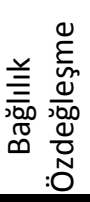 } & A-ilkokul & 135 & 3.49 & .88 & G. Arası & 1.43 & 2 & 2.52 & \multirow{4}{*}{1.052} & \multirow{4}{*}{.350} & \multirow{4}{*}{---} \\
\hline & B-Ortaokul & 154 & 3.37 & .78 & G. İçi & 269.3 & 395 & .22 & & & \\
\hline & C-Lise & 109 & 3.51 & .80 & Toplam & 270.7 & 397 & & & & \\
\hline & Toplam & 398 & 3.45 & .82 & & & & & & & \\
\hline \multirow{4}{*}{ 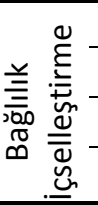 } & A-ilkokul & 135 & 3.63 & .82 & G. Arası & .018 & 2 & 2.52 & \multirow{4}{*}{.016} & \multirow{4}{*}{.984} & \multirow{4}{*}{---} \\
\hline & B-Ortaokul & 154 & 3.64 & .68 & G. İçi & 226.8 & 395 & .22 & & & \\
\hline & C-Lise & 109 & 3.65 & .77 & Toplam & 226.9 & 397 & & & & \\
\hline & Toplam & 398 & 3.64 & .75 & & & & & & & \\
\hline \multirow{4}{*}{ 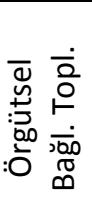 } & A-ilkokul & 135 & 3.27 & .62 & G. Arası & .990 & 2 & 2.52 & \multirow{4}{*}{1.528} & \multirow{4}{*}{.218} & \multirow{4}{*}{--- } \\
\hline & B-Ortaokul & 154 & 3.17 & .49 & G. İçi & 127.9 & 395 & .22 & & & \\
\hline & C-Lise & 109 & 3.27 & .59 & Toplam & 128.9 & 397 & & & & \\
\hline & Toplam & 398 & 3.23 & .57 & & & & & & & \\
\hline
\end{tabular}

Tablo 6'ya göre öğretmenlerin COVID-19 korku düzeyleri ile örgütsel bağlıık ve alt boyutları, öğretmenlerin görev yaptıkları okul kademelerine göre anlamlı farklılık göstermemektedir ( $p>05)$. Öğretmenlerin COVID-19 korkusu ile örgütsel bağlılık düzeyleri arasında ilişki olup olmadığını belirlemek amacıyla yapılan korelasyon analizi sonuçları Tablo 7'de sunulmuştur.

Tablo 7: Öğretmenlerin COVID-19 Korkusu ile Örgütsel Bağlılık Düzeyleri Arasındaki Korelasyon Analizi Sonuçları

\begin{tabular}{lcc}
\hline & & COVID Korkusu \\
\hline \multirow{2}{*}{ Örgütsel Bağ|lıık Uyum } & $\mathrm{r}$ & $-.486^{* *}$ \\
& $\mathrm{p}$ & .000 \\
& $\mathrm{~N}$ & 398 \\
\hline \multirow{2}{*}{ Örgütsel Bağılıık Özdeşleştirme } & $\mathrm{r}$ & $-.163^{* *}$ \\
& $\mathrm{p}$ & .001 \\
Örgütsel Bağlılık İ̧selleştirme & $\mathrm{N}$ & 398 \\
& $\mathrm{r}$ & $-.126^{* *}$ \\
\hline \multirow{2}{*}{ Örgütsel Bağlılık Toplam } & $\mathrm{p}$ & .009 \\
& $\mathrm{~N}$ & 398 \\
\hline
\end{tabular}


Tablo 7'ye göre öğretmenlerin COVID-19 korkuları ile örgütsel bağlılık uyum ( $r=-.486 ; p<.01)$, özdeşleşme $(r=-.163 ; p<.01)$, içselleştirme $(r=-.126 ; p<.01)$ ve örgütsel bağlılı $(r=-.394 ; p<.01)$ düzeyleri arasında negatif yönde anlamlı ilişki olduğu tespit edilmiştir. Bu ilişkide örgütsel bağlılık ile uyum orta düzeyde iken; özdeşleşme ve içselleştirme düşük düzeydedir.

Öğretmenlerin COVID-19 korkularının, örgütsel bağlılıklarını yordayıp yordamadığına ilişkin yapılan regresyon analizi sonuçları Tablo 8'de sunulmuştur.

Tablo 8: Öğretmenlerin COVID-19 Korkularının Örgütsel Bağlıııklarını Yordayıp Yordamadığına illişkin Regresyon Analizi Sonuçları

\begin{tabular}{|c|c|c|c|c|c|c|}
\hline Bağımsız Değişken & Bağımlı Değişken & B & Std. Hata & $(\beta)$ & $\mathbf{t}$ & $\mathbf{p}$ \\
\hline \multirow{2}{*}{ COVID-19 } & \multirow{2}{*}{ Örgütsel Bağlılık Uyum } & 3.778 & .127 & & 29.702 & .000 \\
\hline & & -.481 & .043 & -.486 & -11.068 & .000 \\
\hline \multicolumn{7}{|c|}{$R=-.486 ; R^{2}=.234 ; F=122.506 ; p<.001$} \\
\hline \multirow{2}{*}{ COVID-19 } & \multirow{2}{*}{$\begin{array}{l}\text { Örgütsel Bağlılık } \\
\text { Özdeşleşme }\end{array}$} & 3.815 & .117 & & 32.571 & .000 \\
\hline & & -.132 & .040 & -.163 & -3.293 & .001 \\
\hline \multicolumn{7}{|c|}{$R=-.163 ; R^{2}=.024 ; F=10.847 ; p<.001$} \\
\hline \multirow{2}{*}{ COVID-19 } & \multirow{2}{*}{$\begin{array}{l}\text { Örgütsel Bağlılık } \\
\text { İçselleştirme }\end{array}$} & 3.901 & .108 & & 36.184 & .000 \\
\hline & & -.093 & .037 & -.126 & -2.535 & .012 \\
\hline \multicolumn{7}{|c|}{$R=-.126 ; R^{2}=.013 ; F=6.427 ; p<.001$} \\
\hline \multirow{2}{*}{ COVID-19 } & \multirow{2}{*}{ Örgütsel Bağlılık Toplam } & 3.839 & .075 & & 50.980 & .000 \\
\hline & & -.220 & .026 & -.394 & -8.536 & .000 \\
\hline$R=-.394 ; R^{2}=.153 ; F$ & $; p<.001$ & & & & & \\
\hline
\end{tabular}

Tablo 8'e göre öğretmenlerin COVID-19 korkuları, örgütsel bağlılık $\left(r^{2}=.155 ; p<.01\right)$ ve uyum $\left(r^{2}=.236 ; p<.01\right)$ düzeylerini anlamlı bir şekilde negatif yönde yordadığı; özdeşleştirme $\left(r^{2}=.027 ; p<.05\right)$ ve içselleştirme $\left(r^{2}=.016 ; p<.05\right)$ düzeyleri anlamlı yordasa da çok küçük düzeyde yordadığı ortaya çıkmıştır. Öğretmenlerin COVID-19 korkuları, örgütsel bağılıılarındaki toplam varyansın \%15,5'ini ve örgütsel uyum düzeylerindeki toplam varyansın \%23,6'sını açıklamaktadır. Başka bir ifadeyle öğretmenlerin COVID-19 korkuları, örgütsel/okula bağlılıkları ve örgütsel bağlılık uyum düzeylerini olumsuz etkilemektedir. Öğretmenlerin COVID-19 korkuları arttıkça, örgütsel/okula bağlııkları ve örgütsel bağlıık uyum düzeyleri azalmaktadır.

\section{Tartışma, Sonuç ve Öneriler}

Bu çalışmada; pandemi sürecinde etkilenen gruplardan biri olan öğretmenlerin COVID-19 korkusu ile örgütsel bağlılıkları arasındaki ilişkinin incelenmesi amaçlanmıştır. Çalışmaya katılan öğretmenlerin COVID-19 korkuları cinsiyetlerine göre anlamlı farklılık göstermemektedir. Duman'nın (2020) üniversite öğrencilerinin COVID-19 korkusu ve belirsizliğe tahammülsüzlük üzerine yapmış olduğu çalışmasında öğrencilerin COVID-19 korkusu puan ortalamalarının cinsiyet değişkenine göre anlamlı farklılık olmadığını belirtmiştir. Cao ve arkadaşları (2020) üniversite öğrencileri üzerinde yaptıkları araştırmalarında pandeminin sebep olduğu stres ve negatif duygulanımlarda cinsiyete göre anlamlı farklılık görülmediğini raporlamışlardır. Fakat Bakioğlu vd. (2020) yetişkin bireyler üzerinde yapmış olduğu araştırmada COVID-19 korkusunun kadınlarda anlamlı düzeyde daha yüksek olduğunu bulmuştur. Bu farklılaşmanın erkek katılımcıların sayısındaki yetersizliğin sonuçları etkileyen bir sınırlılık olarak görülmesinden kaynaklanmaktadır.

Lisans mezunu olan öğretmenler, lisansüstü öğretmenlere göre COVID-19'dan daha fazla korku duymaktadır. Bu durum lisans mezunu öğretmenlerin yaş ortalamasının yüksek lisans düzeyindeki öğretmenlere göre daha yüksek olmasından kaynaklanabilir. Aynı şekilde kıdem yılı arttıkça öğretmenlerde COVID-19 korkusunun arttığı da görülmektedir. Bu sonuçların öğretmenlerin 
yaş düzeyleri ile yakından ilişkili olduğu görülmektedir. Çünkü çalışmamızda öğretmenlerin COVID-19 korkuları yaşlarına göre anlamlı farklılık göstermektedir. 51 yaş ve üzerinde olan öğretmenlerin COVID-19 korku düzeyleri, diğer yaş gurubundaki öğretmenlerin korku düzeylerinden daha yüksektir. Başka bir ifadeyle, 51 yaş ve üzerinde olan öğretmenlerin Covid-19 korku düzeyleri, 50 yaş ve altındaki öğretmenlerin COVID-19 korku düzeylerinden daha fazladır. Bakioğlu vd. (2020) yetişkinler üzerinde yapmış olduğu çalışmada katıımcıların yaşları ile COVID-19 korkusu puanları arasında anlamlı bir ilişki bulunmadığını, 18-76 yaş aralı̆̆ındaki bireylerin hepsinde COVID-19 korkusunun aynı düzeyde olduğu görülmüştür. Literatür ile farklılaşan bu durumun öğretmenlerin kalabalık ve yüz yüze çalışma ortamına sahip olmalarından kaynaklandığı düşünülmektedir.

Öğretmenlerin örgütsel bağlılıkları ile örgütsel bağlılık özdeşleşme ve içselleştirme düzeyleri cinsiyetlerine göre anlamlı farklılık göstermemektedir. Ancak, erkek öğretmenlerin örgütsel bağlılık uyum düzeyleri, kadın öğretmenlerin uyum düzeylerinden daha yüksektir. Kılıç (2011) araştırmasında örgütsel bağlıı̆̆ın alt boyutu olan özdeşleşme alt boyutunda cinsiyete göre anlamlı farklılık bulmuştur. Bu farklılık detaylı incelendiğinde kadın öğretmenlerin özdeşleşme düzeylerinin erkek öğretmenlerin özdeşleşme düzeylerinden daha düşük bulmuştur. Buna karşın Aras (2012) yapmış olduğu araştırmada örgütsel bağlılık ile cinsiyet arasında anlamlı farklılık bulamamıştır.

Öğretmenlerin örgütsel bağlılık içselleştirme düzeyleri yaşlarına göre anlamlı farklılık göstermezken; örgütsel bağlııkları ile uyum ve özdeşleşme düzeyleri yaşlarına göre anlamlı farklılık göstermektedir. 51 yaş ve üzerinde olan öğretmenlerin örgütsel bağlıık uyum düzeyleri, 31-40 yaş ve 41-50 yaş arası öğretmenlerin uyum düzeylerinden daha yüksektir. 51 yaş ve üzerinde olan öğretmenlerin örgütsel bağlılık özdeşleşme düzeyleri, 31-40 yaş arası öğretmenlerin özdeşleşme düzeylerinden daha yüksektir. Son olarak 51 yaş ve üzerinde olan öğretmenlerin örgütsel bağlılık düzeyleri, 31-40 yaş ve 41-50 yaş arası öğretmenlerin örgütsel bağlıık düzeylerinden daha yüksektir. Gülle (2013) yapmış olduğu çalışmasında yaş değişkeni ile örgütsel bağlılı̆ın özdeşleşme alt boyutu arasında anlamlı farklılık bulmuştur. Bu farklılıkları incelediğimizde yaş arttıkça örgütsel bağlıık düzeyinin arttığını tespit etmiş̧ir.

Öğretmenlerin örgütsel bağlııkları ile uyum ve özdeşleşme düzeyleri eğitim durumlarına göre anlamlı farklılık göstermezken; lisans mezunu olan öğretmenlerin örgütsel bağılık içselleştirme düzeyleri, lisansüstü mezun olan öğretmenlere göre daha yüksektir. Buna karşın Tulunay (2010) yapmış olduğu çalışmasında öğretmenlerin mezuniyet durumları ile örgütsel bağıııı ve tüm alt boyutları arasında anlamlı farklııı bulamamıştır.

Öğretmenlerin örgütsel bağılıık uyum ve özdeşleşme düzeyleri öğretmelerin kıdemlerine göre anlamlı farklılık göstermemektedir. Ancak, 21 yıl ve üzeri kıdeme sahip olan öğretmenlerin örgütsel bağlılıkları ile içselleştirme düzeyleri, 10 yıl ve altı kıdeme sahip olan öğretmenlerin örgütsel bağlılıkları ile içselleştirme düzeylerinden daha olumludur/yüksektir. Yine 21 yıl ve üzeri kıdeme sahip olan öğretmenlerin örgütsel bağlılıkları ile içselleştirme düzeyleri, 11-20 yıl arası kıdeme sahip olan öğretmenlerin örgütsel bağlııkları ile içselleştirme düzeylerinden daha olumludur/yüksektir. Uygur (2010) araştırmasında ilköğretimde görev yapan öğretmenlerin örgütsel bağlılığın içselleştirme ve özdeşleşme alt boyutlarında öğretmenlerin mesleki kıdemlerini arttıkça bu iki boyuta ilişkin algılarının da arttı̆̆ını söylemiştir.

Covid-19'a dair bulaşma ve ölüm oranları bireylerin psikolojik olarak rahatsız olmasına ve korku yaşamalarına sebep olabilmektedir. Covid-19 nedeniyle meydana gelen korku, sosyal yaşamda diğer bireylere karşı ayrımcılık yapılmasına yol açabilmekte ve hastalı̆ı̆n etkilerini şiddetlendirebilmektedir (Ahorsu vd., 2020). Okullar da yüz yüze etkileşimin yüksek olduğu dolayısıyla bulaşın da yüksek olabileceği kurumlardandır. Virüsün bulaşma hızı, hastalığa yakalanma ve ölüm oranları öğretmenlerde Covid-19 korkusu yaratabilmektedir. Çalışmamızın sonuçlarına baktığımızda da öğretmenlerin Covid-19 korkusu yüksektir ve bu korku örgütsel bağılıklarını da etkilemektedir. 
Örgütsel bağlılığa baktığımızda bu bağlılığı etkileyen birçok faktör vardır. Bunlardan bazıları; yaş, cinsiyet, medeni durum gibi kişiye ait özelliklerin yanında örgütsel adalet, terfi imkanları, sosyal haklar, çalışma yeri arkadaşları, ödüller, iş güvenliği ve yabancılaşma gibi etmenler mesleğin getirdiği özelliklerdir (Mowday vd., 1982). Bu araştırmadan elde edilen sonuçlara göre öğretmenlerin COVID19 korkuları arttıkça, örgütsel/okula bağlılıkları ve örgütsel bağlılık uyum düzeyleri azalmakta olduğu görülmüştür. Bu süreçte örgütsel bağlılığın azalmasının sebebi iş yerinde iş güvenliğinin sağlanamaması görülebilir. Aynı zamanda okuldan uzak kalmak yabancılaşmaya neden olmuş olabilir. Bu sebeple de öğretmenlerin COVID-19 korkuları, örgütsel/okula bağlılıkları ve örgütsel bağlılık uyum düzeylerini olumsuz etkilemekte olduğu görülmüştür. Öğretmenlerin Covid-19 korkusunu azaltabilmek ve örgütsel bağlılıklarını arttırmak için virüsün temas, bulaş, hastalık seyri konusunda eğitimler verilebilir. Ayrıca öğretmenlere uygulanacak olan aşılama programları var olan Covid-19 korkusunun azalmasına ve eğitimin yüz yüze olarak devam etmesine olanak sağlayabilir. Böylece Covid-19 korkusu azalan öğretmenlerin örgütsel bağılığa olan olumsuz etkilerinin de azalmasına yardımcı olabileceği düşünülmektedir.

\section{Kaynakça}

Ahorsu, D.K., Lin, C-Y., Imani, V., Saffari, M., Griffiths, M. D., Pakpour, A. H. (2020). The Fear of COVID-19 Scale: Development and initial validation. International Journal of Mental Health and Addiction. doi: 10.1007/s11469-020-00270-8

Allen, N. J. \& Meyer, J. P. (1990). Theme asurement and antecedents of affective, continuance and normative commitment to the organization. Journal of Occupational Psychology, 63(1), 1-18.

Aras, A. (2012). Illköğretim okullarında görev yapan müzik öğretmenlerinin mobbıng (yıldırma) yaşama düzeyleri, örgütsel bağlılık ve iş doyumları arasındaki ilişkiler (Doktora Tezi). Gazi Üniversitesi, Ankara.

Avcı, N. ve Küçükusta D. (2009). Konaklama işletmelerinde örgütsel öğrenme, örgütsel bağlılık ve işten ayrılma eğilimi arasındaki ilişki. Anatolia: Turizm Araştırmaları Dergisi, 20(1), 33-44.

Bakioğlu, F., Korkmaz, O., \& Ercan, H. (2020). Fear of COVID-19 and positivity: mediating role of intolerance of uncertainty, depression, anxiety, and stress. International Journal of Mental Health and Addiction https://doi.org/10.1007/s11469-020-00331-y

Balay, R. (2000). Özel ve resmi liselerde yönetici ve öğretmenlerin örgütsel bağlıı̆̆ı (Doktora Tezi). Ankara Üniversitesi, Ankara.

Balay, R. (2014). Yönetici ve öğretmenlerde örgütsel bağlılık. Ankara: Pegem Akademi Yayınları.

Brink, P. J. \& Wood, M. J. (1998). Advanced design in nursing research. Sage.

Cao, W., Fang, Z., Hou, G., Han, M., Xu, X., Dong, J., Zheng, J., 2020. The psychological impact of the COVID-19 epidemic on college students in China. Psychiatry Research, 287, 112934. https://doi.org/10.1016/j.psychres.2020.112934

Colizzi, M., Bortoletto, R., Silvestri, M., Mondini, F., Puttini, E., Cainelli, C., Zoccante, L., (2020). Medically unexplained symptoms in the times of Covid-19 pandemic: a casereport. Brain Behav. Immun., 100073. https://doi.org/10.1016/j.bbih.2020.100073.

Duman, N. (2020). Üniversite Öğrencilerinde COVID-19 Korkusu ve belirsizliğe tahammülsüzlük. The Journal of Social Science, 4, 8. DOI: 10.30520/tjsosci.748404

Dumay, X., Galand, B. (2012). The multilevel impact of transformational leadership on teacher commitment: Cognitive and motivational pathways. British Educational Research Journal, 38(5), 703-729. doi:10.1080/01411926.2011.577889

Eminoğlu Küçüktepe, S., \& Erden, M. (2017). İlköğretim öğretmenlerinin mesleki etkililik algılarının incelenmesi. Turkish Studies- International Periodical for the Languages, Literature and History of Turkish or Turkic, 12/28, 245-258.

Erdoğan, Ç. (2012). Ilköğretim okullarında güven kültürü ve önyargı ile ilişkisi (Yayımlanmamış doktora tezi). Ankara Üniversitesi, Ankara.

Eren, E. (2015). Örgütsel davranış ve yönetim psikolojisi. İstanbul: Beta Yayın

Firestone, W. A., Pennel, J. R. (1993). Teacher commitment, working conditions and differential incentive policies. Review of Educational Research, 63(4), 489-525.

Gül, H. (2002). Örgütsel bağlılık yaklaşımlarının mukayesesi ve değerlendirilmesi. Ege Akademik Bakış Dergisi, 2(1), 37-55. 
Gülle, M. (2013). Beden eğitimi ve spor öğretmenlerinin okul ortamında maruz kaldıkları yıldırma algıları ve örgütsel bağlılık düzeylerinin incelenmesi (Yüksek Lisans Tezi). Sakarya Üniversitesi, Sakarya.

Güllüoğlu, Ö. (2011). Örgütsel iletişim doyumu ve kurumsal bağlılık. Konya: Eğitim Kitabevi Yayınları.

Gümüş, S. ve Sezgin, B.(2012). Motivasyonun örgütsel bağlılığa ve performansa etkisi. Konya: Hiperlink Yayınları.

İç İşleri Bakanlığı (2020). 30 ì Büyükşehir ve Zonguldak'a giris,/çıkış kısıtlanması 15 gün uzatıldı. Available from https://www.icisleri.gov.tr/30-buyuksehir-ve-zonguldaka-giriscikislar-daha-once-belirlenen-usul-veesaslaragore-15-gun-uzatildi.

Kaya, K., Küçük, F. ve Arslan, B. (2017). Eğitimcilerde tükenmişlik sendromu ve kurumsal bağlılık. İstanbul: Kriter Yayıncilık.

Kılıç, Ş. (2011). Illköğretim okulu öğretmenlerinin örgütsel sinizm ve örgütsel bağlılık düzeyleri arasındaki ilişki (Keçiören IIlçesi Örneği) (Yüksek Lisans Tezi). Hacettepe Üniversitesi, Ankara.

Lai, T. T., Luen, W. K., Chai, L. T., Ling, L. W. (2014). School principal leadership styles and teacher organizational commitment among performing schools. Journal of Global Business Management, 10(2), 67.

Meyer, J. P., \& Allen, N. J. (1991). A three-component conceptualization of organizational commitment. Human Resource Management Review, 1(1), 61-89.

Mowday, Richard T., Porter, Lyman W., Steers, Richard M. (1982). Employee organization linkages, the psychology of commitment, absenteeism and turnover. Academic Press, Inc.: New York.

Ornell, F., Schuch, J.B., Sordi, A.O., Kessler, F.H.P., 2020. Pandemic fear" and COVID-19: mental health burden and strategies. Braz. J. Psychiatry. https://doi.org/10.1590/ 1516-4446-2020-0008.

Starnes, B. J., Truhon, S. (2006). A primer on organizational commitment. Human Development an Leadership Division. http://asqhdandl.org/index.html.

Tulunay, Ö. (2010). Sınıf öğretmenlerinin tükenmişlik düzeyleri ve örgütsel bağlılık ve örgütsel iletişim ile ilişkisi (Sivas il Örneği) (Yüksek Lisans Tezi). Kırıkkale Üniversitesi, Kırıkkale.

Uygur, M. (2010). ilköğretim okulu yöneticilerinin kültürel liderlik rollerini gerçekleştirme düzeyleri ile öğretmenlerin örgütsel bağlılığı arasındaki ilişki (Yüksek Lisans Tezi). Selçuk Üniversitesi, Konya.

Wang, C., Pan, R., Wan, X., Tan, Y., Xu, L., Mclntyre, R.S., \& Ho, C., (2020). A longitudinal study on the mental health of general population during the COVID-19 epidemic in China. Brain. Behav. Immun. https://doi.org/10.1016/j.bbi.2020.04.028. 